\title{
The Effects of Classroom Management Styles on Students' Motivation and Academic Achievement in Learning English
}

\author{
Thuong Tran Thi \\ Hanoi Law University, Ha Noi City, Vietnam \\ https://orcid.org/0000-0002-2335-0738 \\ Hong-Thu Thi Nguyen \\ Hanoi Law University, Ha Noi City, Vietnam \\ https://orcid.org/0000-0002-6421-7511
}

\begin{abstract}
The aims of this research are to investigate teachers' and learners' perception towards the significance of classroom management in motivating students to learn English; to determine the classroom management styles adopted by teachers during classroom and to identify the extent to which their classroom management styles affect students' English learning motivation and academic achievement. The design of the research is mixed-method one in which an interview and questionnaires are the instruments to collect data. 14 English teachers were asked to be interviewed and 398 students $\left(20110^{\text {th }}\right.$ graders and 197 $12^{\text {th }}$ graders) participated in answering the questionnaires. The outcomes revealed that the various styles in managing their classrooms were displayed; however, each grade possessed a dominant style. Furthermore, the findings showed that each style of classroom management exerted impact with different levels and dimensions on students' English learning motivation. Remarkably, Authoritative style demonstrated the most positive influence on students' English learning motivation and academic achievement. Based on these findings, some implications for managing classroom were drawn out, which emphasized the adoption of Authoritative style and the reduction of some negative aspects of the other styles.
\end{abstract}

Keywords: Classroom management styles; English learning; Motivation; Academic achievement; Teacher controls

\section{Introduction}

Education has been seen as a multi-tasking job involving not only teaching knowledge but shaping the ethical values and codes of conduct in students as well. Thus, teachers as "the nucleus of all formal learning" are being put under growing pressure on how to effectively handle both tasks 
(Chamundeswari, 2013). According to Moreno Rubio (2009), one significant element that contributes to a successful teacher regardless of a profound content knowledge of his or her subject is classroom management skill. It is, thus, obvious that the study of classroom management has become an important aspect of teacher development. It is contended that classroom management could exert influences on the learning environment for students, which, as a result, affects both their academic competencies and emotional development (Kratochwill, n.d).This can be considered as a rationale for much research into the effect of classroom management on students' academic achievement and students' behavior. Anderson, Evertson \& Brophy, (1979) and Brophy \& Evertson (1976) maintained that managerial behaviors of teachers and student achievements were closely connected. Good and Grouws (1977) strengthened the previous research result by showing that teachers whose classes had better academic performance possessed better management skills. As to students' behavior, much research highlighted that teacher's classroom management practices exhibited a dramatic, positive effect on diminishing troublesome behavior, especially disruptive or aggressive one in the classroom. In the book "Comprehensive Classroom Management: Creating Communities of Support and Solving Problems," Jones and Jones (2007) mentioned one more aspect that the teacher managerial strategies affected students, which is students' motivation. However, although motivation is an important factor contributing to students' achievement, hardly can studies that thoroughly investigates its relationship with teacher's management practices be found.

With regard to the above stated, the researchers' aim is first to find out the perspectives of students on classroom management styles adopted during the course. In addition, the effects of classroom management styles on students' English learning motivation and academic achievement are also the researchers' concerns. Besides, it is the researchers' desire to investigate the techniques of building positive motivation through adopting classroom management styles.

In brief, to achieve these aims above, this paper is conducted to answer the following questions:

1. What are the perspectives of students on classroom management styles adopted during the course?

2. To what extent do classroom management styles affect students' English learning motivation and academic achievement?

3. What are teachers' beliefs on building positive motivation through adopting classroom management styles?

\section{Literature review}

\subsection{Classroom management styles}

Although classroom management is the frequently used term, there are various different viewpoints surrounding its exact definition. Doyle (1986) identified classroom management as "the actions and strategies teachers use to solve the problem of order in classrooms" (p. 397). It means that Doyle is concerned about how the disciplines in classrooms were effectively enforced 
when problems arise. In a broader and more widely accepted sense, Moore and Hansen (2012) did not only claim that classroom management was the immediate reaction of teachers against problems in classroom, but also expanded the meaning of classroom management to "the establishment and maintenance of the classroom environment so that educational goals can be accomplished"(p.53). In other words, they emphasized a preventive approach or the routine procedure, which was conducive to students' learning. In the researcher's viewpoint, classroom management and discipline should not be interchanged and considered to be the same. Classroom management can be regarded as an "umbrella" to help teacher to oversee a multitude of learning activities such as social interaction, and student behavior (Martin, Yin \& Baldwin, 1998). Classroom management relates to procedures and routines to the point of becoming rituals, whereas classroom discipline concerns the way people behave and is about self-control. Based on this distinction, it can be seen that Doyle's definition of classroom management is indeed the definition of classroom discipline. To sum up, it is commonly accepted that classroom management is connected to creating a task-oriented environment, predictable and consistent (Wong \& Wong, 2005).

\subsection{Aspects of classroom management}

As mentioned above, classroom discipline and classroom management are conventionally used interchangeably. However, discipline is only one of the many other aspects of classroom management. It has been claimed that classroom management was not simply a "bag of tricks" that was used identically among different teacher generations but it was a multi-faceted endeavor that goes beyond controlling students' behavior (Evertson \& Weinstein, 2006). As a multi-faceted construct, classroom management comprises three broad aspects: instructional management, people management and behavior management (Martin et al., 1998).

To begin with, instructional management consists of sub-aspects such as managing the physical setting of classrooms, establishing daily routines and allotting materials. The way these tasks are conducted influences the whole classroom atmosphere and classroom management styles (Burden, 1995; Kounin, 1970; Weinstein \& Mignano, 1993). Brophy (1988) maintained that teachers were required to possess good instructional skills so that they could plan and organize the activities more efficiently and make transitions between these activities smooth. For example, teachers can deliver instruction step by step, starting with structuring and then modeling it. By doing so, teachers can enable students to be on-task.

Concerning people management, it is understood that to manage a large group of students is not an easy task. It requires teachers to take students' different personalities into consideration when dealing with them. In other words, how to make students cooperate and comply is the mission of teachers. To be more specific, people management includes what teachers believe about students as persons and behaviors teachers do to convince students to do something for the purpose of attaining some outcomes (Hill, 2003). For instance, a teacher gives her students the opportunity to establish 
their own daily routines if she believes that her students prefer self-discipline. Noticeably, teacher-student relationship is properly the most significant subaspect of people management. In fact, many researchers have concurred that students' academic achievement and proper behavior are enforced if a strong teacher-student relationship covers the classroom atmosphere (Burden, 1995; Glasser, 1986; Weinstein, 1996). Marzano and Marzano (2003) have indicated that "the most effective teacher-student relationships are characterized by specific teacher behaviors: exhibiting appropriate levels of dominance; exhibiting appropriate levels of cooperation; and being aware of high-needs students."

Finally, behavior management can be regarded similar to discipline, but they differ in the way that behavior management is prone to prevention rather than immediate reactions to students' behaviors. Precisely, behavior management includes setting rules, establishing a reward structure and providing opportunities for student input (Martin et al., 1998). To illustrate, a system of rewards and punishments can be set at the beginning of the school year. In the study of Emmer et al. (1980), they distinguished between efficient and inefficient classroom managers based on the manner those managers develop and employ rules. According to Weinstern and Mignano (1993), the order of classroom is similar to the conversation which can only be successfully carried on if both teachers and students agree to involve in. Therefore, only when students are motivated to comply with the rules do classroom rules take effect.

\subsection{Types of classroom management styles}

It can be readily acknowledged that classroom management styles vary among teachers because of their different personalities and ideologies. Therefore, hardly can researchers identify all the existing types of classroom management styles. However, there is a consensus among researchers that teacher classroom management styles can be categorized into four types based on two dimensions: the level of control exerted over students and that of the teachers' involvement with students (Baumrind, 1971; Dunbar, 2004).

Besides the variables of Student Control and Student Involvement, Chamundeswari (2013) added the variable of Knowledge into his Classroom Management Styles Inventory. In this study, the researchers also include Knowledge variable in each classroom management style as this can influence one's classroom management style according to the researchers' viewpoint. There are a number of taxonomies regarding teacher classroom management styles; however, the researcher only utilized the widely accepted classification developed by Baumrind (1971), which comprises four types: Authoritative style, Authoritarian style, Indulgent style and Permissive style.

\subsubsection{Authoritative}

Baumrind (1971) defined this style of teachers as exhibiting high expectations of suitable behaviors, articulating clearly about the reasons for a particular behavior to be accepted while others are not and maintaining a harmonious relationship with students. Dunbar (2004) was also in agreement with Baumrind; however, he provided a more detail description of this style. 
According to him, an authoritative teacher displays limits and controls over students but still facilitates independence at the same time (Dunbar, 2004). Authoritative teachers usually use informal or non-controlling language when communicating with students. As in the dissertation of Chang (2012), another way to name this style is "Autonomy-Supportive." It is obvious that building a classroom environment that fosters students' independence in thinking and making choices with the support of teachers is the critical goal of this style. For example, students can be involved in the discussion about establishing classroom rules or their expectations. It means that authoritative teachers carefully take students' needs, interests and preferences into consideration.

\subsubsection{Authoritarian}

As opposed to the afore-mentioned style, authoritarian teachers appear like a boss in classroom settings. Chang (2012) called this style of teacher "Highlycontrolled" teacher. It can be interpreted that firm limits and controls over students are utilized by authoritarian teachers (Dunbar, 2004; Chang, 2012). Rarely does an authoritarian teacher explain the reasons why or why not a certain behavior is acceptable, even though the rules are explicitly informed to students. In addition, those who exhibit authoritarian styles tend to offer rewards as a means to motivate students (Woolfolk \& Hoy, 1990). Besides, punishment or negative consequences are also used when students refuse to comply with the rules.

\subsubsection{Indulgent}

In the classification of teacher classroom management style presented by Dunbar (2004), this style is called "Laissez-faire" style. Indulgent or laissez-faire teachers are prone to establish few demands and controls over their students. Teachers are hesitant to enforce the rules. If discipline is imposed, there is a tendency of inconsistency. The reason is that these teachers try to be a friend of students rather than a role model or an educator (Jones, n.d). Students who, in classes, are facilitated by an indulgent teacher are often given permission to do their favourite things (Dunbar, 2004). In other words, students are granted much freedom in classroom. Baumrind (1971) stated that indulgent teachers enthusiastically support their students to seek their own ends using any reasonable means.

\subsubsection{Permissive}

Permissive or Indifferent teachers are defined as being deficient in both involvement with students and control over them (Baumrind, 1971). Also, Permissive style is similar to Indulgent style in certain extents in which teachers set few or no limits and controls over students (Dunbar, 2004). However, unlike Indulgent teachers, Permissive teachers always feel that preparation before class is not necessary. Therefore, they tend to spend little time for classroom preparation as well as using repetitively one type of material; lesson plans year after year (Dunbar, 2004). In addition, discipline is non-existent in the class undertaken by permissive teachers (Baumrind, 1971). In other terms, a nonpunitive classroom is facilitated. As can be seen, this style of teacher reflects an uninterest and the lack of dedication to pedagogic career. 


\subsection{Language learning motivation}

\subsubsection{Importance of motivation in language learning}

According to Terrell H. Bell (as cited in Ames, 1990), "There are three things to remember about education. The first one is motivation. The second one is motivation. The third one is motivation." This illuminates the importance of motivation in the learning process. Indeed, whether a learner possesses a potential capability or not, learning a foreign language still requires an enormous amount of effort and patience. Apparently, effort and patience originate from one's dynamic. Once learners are well aware of their goal to learn a language or desire to achieve success in learning because of some inside or outside sources, the learning process can easily occur. As a result, sooner or later motivated learners will fulfill their dream of success. Gardner (1972), Wigfield and Wentzel (2007) stated that motivation can influence language learning outcomes independently from language aptitude. It is, thus, evident that motivation is one of the indispensable factors driving the language learning process.

\subsubsection{Classifications of students' language learning motivation}

Ryan and Deci (2000) highlighted that "to be motivated is to be moved to do something." In other words, one who is motivated will be engaged in doing and focusing attention on the tasks. Usually, it has been described as "the intensity of behavior, the direction of behavior, and the duration of behavior" (Ames, 1990). However, when it comes to mention motivation in language learning, this term shows its complexity as it is influenced by social and cultural factors. As Gardner wrote, motivation to learn a language is the combination of effort and desire as well as a positive attitude toward the target language (Gardner, 1985). It means that motivation to learn a language can come from an inner drive or it may be the result of the social factors influencing learners' language attitude. In the psychological field, motivation is defined as a psychological process that causes stimulation, direction and the assertive maintenance of voluntary action that is closely related to goals (Mitchell, 1982). As there are a number of definitions for motivation in language learning, there also exist many classifications of learners' motivation. Gardner and Larmbert (1972) first presented these concepts in their Socio-educational Model. According to them, motivation to learn a language could be divided into two types: Integrative and Instrumental, and the emphasis was placed on the first type. Integrative motivation is defined as the desire to be exposed to the target language, communicate or even integrate with the community of the target language (Keblawi, n.d). Meanwhile, people who display instrumental motivation regard learning a language as a tool to achieve their goals such as getting a job or passing an examination (Gardner, 1985). In other words, instrumental motivation serves to fulfill more purposeful functions when learning a language.

In Self-determination theory, motivation is categorized into Intrinsic and Extrinsic motivation. Intrinsic motivation, which is seen as a cognitive approach to motivation, is related to the internal motives that drive a person to perform a certain action. To be specific, people engage in a particular activity as a result of internal rewards such as pleasure, enjoyment or satisfaction of curiosity. As Deci claimed intrinsic motivation brings about feelings of competence and self- 
determination (1975). In contrast, extrinsic motivation is considered as a stimulation approach to motivation, that is; it requires external rewards for a behavior to be exhibited. Brown (2007) pointed out that external incentives such as money, prizes, positive feedback, grades could have an impact on extrinsic motivation.

\subsubsection{Relationship between classroom management and students' English learning motivation}

In a study on teacher characteristics and their effects on students' attitudes, Açıkgöz (2005) stated that to facilitate a learnable and teachable classroom climate, pedagogical and professional characteristics of teachers are not enough but personal traits are the most influential in this case. Evidently, classroom management styles of teachers which are partly shaped by teachers' personal characteristics also nourish an effective learning atmosphere. Açıkgöz (2005) and Morehouse (2007) claimed that classroom with a and encouraging atmosphere exert a positive influence on students' intrinsic motivation. That is to say, classroom management styles which enable such favorable ambience also strengthen the intrinsic motivation of students. Alternatively, Nation (2001) observed that "without the engagement or aroused the attention of the students, there can be little opportunity for other conditions favoring learning to take place" (p. 63). Accordingly, teachers' management is also inefficient in this case. It is, thus, evident that students' learning motivation can also produce some adverse effects on classroom management, particularly teacher classroom management styles.

\section{Methods}

\subsection{Population}

Participants of this study comprised of 14 English teachers (9 males and 5 females) whose ages were from 28 to 42 and their teaching experience was from 5 to 17 years; $201\left(10^{\text {th }}\right)$ graders and $197\left(12^{\text {th }}\right)$ graders. The $10^{\text {th }}$ graders at this age were experiencing a critical stage of their education and psychology. As they had left their secondary school and been exposed to a new environment of high school, everything they encountered in school life could have negative or positive impact on their characters and studying. Evidently, at this deciding stage students could be either motivated or demotivated to learn by a number of factors in which teachers deem to be the most influential entities. Of the five 10th grades, 10A1 was the only gifted-class with the outstanding students chosen from the entrance exam. The $12^{\text {th }}$ graders were the at the last-stage of the high school duration with the development in learning experience, self-efficacy, autonomy and mature in psychology. To select student samples for the study, the researcher employed stratified sampling technique and 398 students were involved in.

\subsection{Data collection instruments}

The questionnaires, pretests and post- tests, in - depth interviews are the data collection instruments in this research. The questionnaire was used to collect data regarding the management styles of the English teachers and how the teachers' management styles influence the students' motivation in learning English. The questionnaire for students consists of 2 parts. Part 1 asks students 
to identify their teachers' management styles by selecting any characteristic that their teachers exhibit. Part 2 of the questionnaire requires students to rate teacher control and motivation levels in the learning course based on the 5-point Likert scale. Furthermore, the participants of the two groups had taken 2 types of test including pretests and post-tests to check the effect of teachers' management styles on their academic achievement. The pretests were taken by all the $10^{\text {th }}$ graders at the beginning of the course to compare the input levels between the grades when there had been no control and teaching from teachers. The post-tests were conducted at the end of the course as a final exam. The teacher scored their outcomes based on 10-point scale. Using interview guide, the researchers can assure that the same basic lines of inquiry are pursued with each person interviewed. It means that the guide will help interview many people systematically. Therefore, it will facilitate the researchers in data analyzing phase. The questions in the interview guide are asked based on the areas that the researchers want to investigate. Precisely, the first question in the interview guide deals with the teachers' perception towards the impact of their classroom management styles on students. The rest questions figure out the classroom management styles of each interviewer by exploring 3 variables of classroom management style: Knowledge, Student Involvement and Student Control.

\subsection{Data collection and analysis}

The data from the survey were analyzed by means of both qualitative and quantitative approaches with the assistance of SPSS 25.0 software. A reliability analysis was conducted as the first phase of the data analysis process. These findings made good unidimensionality validity for variables to ensure the proper data treatment for the research questions. The demographic information of the participants, the proportion of classroom management styles were analyzed based on frequency descriptive test. The investigator employed Independent t-test to test the difference in teachers' management control and motivation levels between grades $10^{\text {th }}$ and $12^{\text {th }}$. Then, Paired-sample T-test was employed to measure the difference between pretests and post-tests among 10th graders and regression test was used to evaluate the correlation between teacher control levels, motivation level and academic achievement. For question number 3 , the researcher utilized interview to gather information because by face-to-face interviewing teachers, it is much easier to get their viewpoints on a matter.

\section{Findings}

\subsection{Classroom Management Styles Adopted in graders 10-12}

Table 1 presents the information on classroom management styles adopted in the $10^{\text {th }}$ and $12^{\text {th }}$ grades.

Table 1: Proportion of classroom management styles adopted in graders 10-12

\begin{tabular}{ccccccccccccc}
$\begin{array}{c}\text { Grades } \\
\text { Class styles }\end{array}$ & $\mathbf{1 0}$ & $\mathbf{1 2}$ & $\mathbf{1 0 A 1}$ & $\mathbf{1 0 A 2}$ & $\mathbf{1 0 A 3}$ & $\mathbf{1 0 A 4}$ & $\mathbf{1 0 A 5}$ & $\mathbf{1 2 C} \mathbf{1 2 C 2}$ & $\mathbf{1 2 C 3}$ & $\mathbf{1 2 C 4}$ & $\mathbf{1 2 C 5}$ \\
\hline Authoritarian & 26,4 & 7,6 & 5,0 & 31,7 & 42,5 & 32,5 & 20,0 & 5,1 & 2,5 & 2,5 & 17,5 & 10,3 \\
Authoritative & 41,8 & 31,3 & 40,0 & 46,3 & 37,5 & 42,5 & 42,5 & 17,9 & 37,5 & 32,5 & 27,5 & 41,0 \\
Indulgent & 23,4 & 44,9 & 50,0 & 12,2 & 10,0 & 15,0 & 30,0 & 56,4 & 45,0 & 47,5 & 40,0 & 35,9 \\
Permissive & 8,5 & 16,2 & 5,0 & 9,8 & 10,0 & 10,0 & 7,5 & 20,5 & 15,0 & 17,5 & 15,0 & 12,8 \\
\hline
\end{tabular}


As can be seen from Table 1, there is a diverse distribution among the class management styles in 2 groups of $10^{\text {th }}$ grades and $12^{\text {th }}$ grades. In general, authoritarian class type appeared in grades $10^{\text {th }}$ more than in grades $12^{\text {th }}$ with $26.4 \%$ and \& $7.6 \%$ respectively. The authoritative class types made up to $41.8 \%$ in grades 10 th whereas $31.3 \%$ belonged to grades $12^{\text {th }}$. It can be explained that the students in $10^{\text {th }}$ grades were the new ones enrolling in a high school, so they had to be placed in the classes with more powerful instruction and higher control from teachers. Teachers added that classroom management served to maintain students' interest in the subject. There was a converse result in the two class types left with the higher proportion resting with the $12^{\text {th }}$ grades. Particularly, the indulgent class took account approximately half of the $12^{\text {th }}$ grades; meanwhile, the $10^{\text {th }}$ graders possess only $23 \%$. Similarly, the number of 12 th students choosing the permissive option was as twice as the number of 10th students. Therefore, it can be concluded from questionnaire results that Authoritative style were adopted in the 10th grades most of the time. In contrast, indulgent class was the dominant style in the $12^{\text {th }}$ grades.

Going into more details, students of grade $10 \mathrm{~A}$ determined indulgent style to be preferred more than the other types. However, students of $10 \mathrm{C}$ considered the Authoritarian styles as the premier one. The other 10th grades (10A2, A4, A5), by common consent, are identified to belong to Authoritative style. Of 5 grades 12th, only one grade $12 \mathrm{C} 1$ considered authoritative style as the main classroom management style. Meanwhile, four the others rested with the indulgent class style.

Comparing the results from interviews and questionnaires, the researcher comes to a conclusion that teachers of all10 grades exhibited quite various styles of classroom management, namely Indulgent, permissive, Authoritative and Authoritarian styles, of which Permissive and Authoritarian styles were relatively low in the number of votes, whereas Authoritative and Indulgent styles were dominant in grades 10th and 12th respectively. Based on the investigation on the percentage of the classroom management styles maintained in 10th graders and 12th graders, it can be seen that there was difference in classroom traits between the beginners and the last-year students in high school. This is explained for a number of reasons in the open questions and interviews.

\subsection{Difference in teachers' control levels between the grades 10 and 12}

Concerning the management control levels between the grades 10 and 12, the result from the independent sample test indicated that the Sig. value of Levene's Test for Equality of Variances is below 0.5. Therefore, the Sig. (2-tailed) value in the equal variances not assumed was used to take into consideration. 
Table 2: Difference in teachers' control levels between the grades 10 and 12

\begin{tabular}{|c|c|c|c|c|c|c|c|c|c|}
\hline & \multicolumn{2}{|c|}{$\begin{array}{l}\text { Levene's Test } \\
\text { for Equality } \\
\text { of Variances }\end{array}$} & \multicolumn{4}{|c|}{$\begin{array}{l}\text { t-test for Equality of } \\
\text { Means }\end{array}$} & \multirow[b]{2}{*}{$\begin{array}{l}\text { Std. Error } \\
\text { Difference }\end{array}$} & \multicolumn{2}{|c|}{$\begin{array}{c}95 \% \\
\text { Confidence } \\
\text { Interval of the } \\
\text { Difference }\end{array}$} \\
\hline & $\mathbf{F}$ & Sig. & $\mathrm{T}$ & df & $\begin{array}{l}\text { Sig. (2- } \\
\text { tailed) }\end{array}$ & $\begin{array}{l}\text { Mean } \\
\text { Diffe } \\
\text { rence }\end{array}$ & & Lower & Upper \\
\hline $\begin{array}{c}\text { Equal variances } \\
\text { assumed }\end{array}$ & 8,716 & ,003 & $-5,615$ & 397 & , 000 &,- 655 & ,117 & -8884 &,- 426 \\
\hline $\begin{array}{l}\text { Equal variances } \\
\text { not assumed }\end{array}$ & & & $-5,623$ & $\begin{array}{c}386,54 \\
9\end{array}$ & , 000 &,- 655 & ,116 &,- 884 &,- 426 \\
\hline
\end{tabular}

As can be seen from Table 2, the Sig. (2-tailed) value of t-test for Equality of Means is smaller $(0.000)$ than the confidence level $(<0.05)$. It comes to conclusion that there is a slight difference (0.655) in the management control levels between the grades 10 and 12. The lower difference that could be found in the table is 0.426 and the highest difference is 0.884 . It is apparent that in the table 1 , the dominant class styles of the groups are different, meanwhile management control level is the main trait to distinguish the styles. Thus, it is easy to interpret the difference in teachers' management control levels between the grades 10 and 12 .

\subsection{Difference in motivation between the grades $10^{\text {th }}$ and $12^{\text {th }}$}

When it comes to student motivation in learning process, an independent samples test was implemented to compare the difference between the grades 10 and 12.

Table 3: Difference in motivation between the grades 10 and 12

\begin{tabular}{|c|c|c|c|c|c|c|c|c|c|}
\hline & \multicolumn{2}{|c|}{$\begin{array}{c}\text { Levene's Test } \\
\text { for Equality of } \\
\text { Variances }\end{array}$} & \multicolumn{4}{|c|}{ t-test for Equality of Means } & \multicolumn{3}{|c|}{$\begin{array}{l}\text { 95\% Confidence } \\
\text { Interval of the } \\
\text { Difference }\end{array}$} \\
\hline & $\mathbf{F}$ & Sig. & $\mathbf{t}$ & Df & $\begin{array}{l}\text { Sig. (2- } \\
\text { tailed) }\end{array}$ & $\begin{array}{c}\text { Mean } \\
\text { Difference }\end{array}$ & $\begin{array}{l}\text { Std. Error } \\
\text { Difference }\end{array}$ & Lower & Upper \\
\hline $\begin{array}{l}\text { Equal variances } \\
\text { assumed }\end{array}$ & 10,920 & ,001 & $-5,420$ & 397 & ,000 &,- 517 & ,095 &,- 704 &,- 329 \\
\hline $\begin{array}{l}\text { Equal variances not } \\
\text { assumed }\end{array}$ & & & $-5,416$ & 392,391 & 000 & ,095 & ,095 &,- 704 &,- 329 \\
\hline
\end{tabular}

It can be referred from Table 3 that the Sig. (2-tailed) value in the equal variances that is not assumed was opted to be taken into account $(\mathrm{Sig}<0.05)$. Thus, the Sig. (2-tailed) value of t-test for Equality of Means is smaller (0.00) than the confidence level $(<0.05)$. It reveals that there is a slight difference $(0.655)$ in motivation between the grades 10 and 12. The lower difference that could be found in the table is 0.329 and the highest difference is 0.704 . Besides, the figure of the Mean Difference between two variables is not high (0.095). 


\subsection{Effects of class management styles to the academic achievement}

As far as investigating the effects of class management styles to the academic achievement is concerned, the results from Paired Samples Test came out to tell that all the Sig. values (2-tailed) are smaller than the confidence level. This means that there were differences in scores between the pretests and post-tests amongst the 10th grades.

Table 4: Comparison between the pretests and post-tests of 10th grades

\begin{tabular}{|c|c|c|c|c|c|c|c|c|}
\hline & Paired & Differences & & & & & & \\
\hline & & & $\begin{array}{l}\text { Std. } \\
\text { Error }\end{array}$ & $\begin{array}{l}95 \% \text { Co } \\
\text { Interval } \\
\text { Differe }\end{array}$ & $\begin{array}{l}\text { fidence } \\
\text { of the } \\
\text { ce }\end{array}$ & & & \\
\hline & Mean & Deviation & Mean & Lower & Upper & $T$ & df & \\
\hline $\begin{array}{l}\text { pretests and } \\
\text { post-tests 10A1 }\end{array}$ & ,875 & 1,418 & ,224 & 422 & 1,328 & 3,904 & 39 & ,000 \\
\hline $\begin{array}{l}\text { pretests and } \\
\text { post-tests } 10 \mathrm{~A} 2\end{array}$ & 0,988 & 1,227 & 192 & 100 & 875 & 2,545 & 40 & ,015 \\
\hline $\begin{array}{l}\text { pretests and } \\
\text { post-tests 10A3 }\end{array}$ & 1,025 & 1,527 & 241 & ,537 & 1,513 & 4,244 & 39 & , 000 \\
\hline $\begin{array}{l}\text { pretests and } \\
\text { post-tests 10A4 }\end{array}$ & ,975 & 877 & 139 & 195 & 755 & 3,427 & 39 & ,001 \\
\hline $\begin{array}{l}\text { pretests and } \\
\text { post-tests } 10 \mathrm{~A} 5\end{array}$ & 1,025 & 1,423 & ,225 & ,570 & 1,480 & 4,556 & 39 & ,000 \\
\hline
\end{tabular}

In the comparisons with the pretests, the post-test scores in all grades were higher. Obviously, the most significant difference belongs to grade 10A3 with the mean of Paired Differences is 1.025 by a high consent of all the members of the class $(\mathrm{SD}=1.527)$. Looking back to Table 1, $10 \mathrm{~A} 3$ is the only class orienting to Authoritarian management style with $42.9 \%$ in which the teacher is more concerned about the fulfilment of students' needs in the classroom more than controlling them. It can be seen that thanks to the teacher control, students made a lot of efforts and got the certain success with the higher scores at the end of the course. Meanwhile, the grade 10A1 that was mostly based on the indulgent classroom style, had a slight progress with the mean paired difference 0.875 .

\subsection{Correlation between teacher Control levels, Motivation and Academic achievement}

In order to answer the question whether there is a correlation between teacher control levels, motivation and academic achievement or not, a regression test was conducted. 
Table 5: Correlation between control levels, motivation and academic achievement

\begin{tabular}{|c|c|c|c|c|c|c|c|c|}
\hline \multicolumn{9}{|c|}{ Coefficients } \\
\hline & & \multicolumn{2}{|c|}{$\begin{array}{l}\text { Unstandardized } \\
\text { Coefficients }\end{array}$} & \multirow{2}{*}{$\begin{array}{c}\text { Standardiz } \\
\text { ed } \\
\text { Coefficient } \\
\text { s } \\
\text { Beta }\end{array}$} & \multirow[b]{2}{*}{$t$} & \multirow[b]{2}{*}{ Sig. } & \multicolumn{2}{|c|}{$\begin{array}{c}\text { Collinearity } \\
\text { Statistics }\end{array}$} \\
\hline & Model & B & Std. Error & & & & $\begin{array}{c}\text { Tolerand } \\
\text { e }\end{array}$ & VIF \\
\hline 1 & $\begin{array}{c}\text { Academic } \\
\text { achievement }\end{array}$ & 7,615 & ,303 & & 25,166 & , 000 & & \\
\hline & Motivation & -108 & 080 &,- 095 & $-1,352$ & 178 & 996 & 1,004 \\
\hline & Control levels & ,082 & ,057 & 102 & 1,441 & 151 & ,996 & 1,004 \\
\hline
\end{tabular}

It can be seen from Table 5, the Sig. value is higher than 0.05 , and therefore there is not enough evidence to conclude that these variables are correlated. There is a common consensus that various factors affecting the student achievement, in which motivation and teacher control are placed on the prior positions. However, this does not mean that the high or low results of students derives from the classroom management styles.

\subsection{Teachers' beliefs on building positive motivation through adopting classroom management styles}

The answers for this question were received from the interviews with the teachers. It can be reported that the interviewees exhibited quite different attitudes and ideas about the significance of classroom management for motivating students to learn English. A teacher regarded classroom management as a really important factor contributing to students' motivation. Interviewees contended that classroom management played roles in maintaining students' motivation and encouraging students' task motivation as well.

The teachers very flexible in choosing strategies to cope with misbehaviors. In this sense, Mrs Lan doesn't strictly apply the same policy into various circumstances but her decision "depends on the seriousness of the behavior. Her demands for students' learning are also changeable according to the level of specific classes - My demands are different in each class depending on the students' competence. Obviously, at this point she does not express any traits of Permissive style because she always places control and demands on her students to some extent. As can be seen, the control over her students can be ranged from Indulgent styles, Authoritarian to Authoritative style. Ms. Ha expressed her constant care for her students, not only about their learning but also their personal problems. On the one hand, she shows her good attempt in promoting students' performance by helping them to understand more and "acquire the knowledge better when students do not meet her expectation. On the other hand, she also pays attention to students' personal problems and considers it as a mean to get more respect from students as well as tightening the teacherstudent relationship. Moreover, she maintained a friendly and mutualunderstanding and mutual-respect way of communication with students. All of those traits undoubtedly depict Authoritative style. Information with regard to Knowledge aspect also indicates this style of classroom management. 
Specifically, she prepares lesson carefully with the provision of more matters than in the text and vary the activities as many as possible. Besides, she usually checks students' comprehension through asking students to give examples.

Mrs Hai does establish the same rules in each class; however, depending on the specific situation that she follows them or not. She also supports students in relearning accepted behaviors by helping them understand that their behavior is not appropriate and making them realize the bad results if they continue those inappropriate behaviors. As to Student Involvement, Authoritative style is the most remarkable classroom management style adopted in spite of the fact that her class occasionally shows her Indulgent and Authoritarian styles. For example, she is really concerned with the personal problems of students because she could help or give them advice to avoid negative consequences (Authoritative style). Besides, she often maintains "friendly" communication with her students; nevertheless, she also keeps distance in communication" if the situation requires her to do so (Authoritative style, Indulgent style and Authoritarian style). As for knowledge aspect, the variation of classroom management styles is even more complex. She can be of Permissive style when she does not vary in-class activities but only uses group work most of the time. She can also exhibit Indulgent style, Authoritative style or Authoritarian style when it comes to provide more matters than in the texts. This comment is drawn because she "depends on the topic of the text" to introduce additional content. Therefore, sometimes students may find her informative, sometimes not.

When being asked about Student Control aspect, Ms. Lien reported that she did not uniformly respond to different situations. On dealing with misbehaviors, she often 'take[s] students' attitude into consideration before deciding on what treatment should be given". It means she can be of Authoritarian style if students are "aggressive or impolite" or of Authoritative and Indulgent styles when students "express their apologetic attitude". One other evidence is that she does not always impose rules and demands on students. In some cases, she expresses Permissive style as students are obedient and "rules and demands are not necessary". As regards Student Involvement, all of her answers reflect Authoritative and Indulgent style. For instance, in her viewpoint, teachers should be "a friend" of students; hence, paying attention to their personal problems is teachers' way to make friends with students. In terms of Knowledge aspect, she displays Authoritative, Authoritarian style and Permissive style. Precisely, she will vary in-class activities if the lesson is not so difficult. If not, she chooses individual work or pair work as the only activity for students:

"It's quite hard to conduct various activities within the time limit. So, if the lesson is not so difficult, I can provide students with more types of activities, discussion or some funny games for example. If not, I only ask them to do exercise in pairs or individually." (Mrs Hai)

Analyzing details from the interview with the other teachers, the researcher found out that they are prone to be an easy-going teacher. Miss. Hoa reported that she felt "somehow uncomfortable when imposing such rules on [her] students." She can easily forgive students' misbehaviors if they "break the rules for the first time." In addition, she also said that she did not want "the whole class atmosphere to be down and waste too much time on dealing with 
misbehaviors." When it comes to mentioning Student Involvement aspect, she expressed her high consideration towards students' personal problems. She regarded it as a mean to "encourage students to get over their problems and learn harder." Besides, according to her viewpoint, teachers should be friendly and demonstrate no distance in communicating with students. By so doing, "students will feel most comfortable and unpressurized. "In terms of Knowledge aspect, this teacher sometimes disseminates knowledge sufficiently according to the materials without introducing extra content. Furthermore, she does not usually vary in-class activities because "individual work accounts for the majority in [her] classes."

\section{Discussion}

On the premise of the proportion of Classroom management styles adopted in graders 10-12, it can be seen that each class with the distinctive traits was suitable with one type of class management. The difference in ages and grades had an impact on the choosing class style to control. It was obvious that the students in grades 12th with more experience, mature in psychology, learning autonomy capacity and skills were prone to fit the indulgent management type. Whereas, the students in 10th grades who were the first-year ones at high school with a lot of difference and strange from the secondary school, needed more care and control from teachers to have a right pathway in learning. As a consequence, the dominant classroom management styles in grades 10 are Authoritative and Authoritarian styles which in turn manifest high expectations of performance from students, enable progress, and respect for students through active listening. The prior classroom styles in grades 12th were indulgent and Authoritative ones. This finding aligns with the studies by Baumrind (1971) and Dunbar (2004). It is consented that teachers should identify the characteristics, psychological features and academic capacity of students to choose a suitable management style in classroom.

As seen from the obtained results, classroom management styles had an impact on the students' English learning motivation and academic achievement to some extent. In particular, there is a remarkable difference in the scores of pretests and post-tests of the 10th-grade students. It was noticeable that the class managed by authoritative style got higher motivation and better progression than the other styles. It means that the appropriate classroom management had positive effects on student motivation, and their academic achievement, which is in consistent with investigation by Adler (1930) and Dreikurs (1957). They concluded that in a supportive, democratic, and encouraging education environment, students have greater satisfaction and involvement in school with their teachers . As a result, students achieved more success in obtaining the learning goal, in relationship with instructors and participating in academic activities rather than students who have the usual classroom experiences. Obviously, with the encouragement, support and consults from teachers; along with feeling belonging, importance, freedom, and mutual respect in classroom (Djigic \& Stojiljkovic, 2011; Dreikurs et al., 2004; Waterman, 2007), the students become willing to be engaged in classroom, capable to complete their homework and other school tasks (Wessler, 2003). 
The findings from the interview reveal that teachers highly evaluate the effect and the importance of classroom management styles in building a positive education environment, boosting motivation and improving academic achievement. Besides, being aware of the role of management in classroom, teachers identified the appropriate strategies to adapt to the particular contexts. The demands for students' learning are also changeable according to the level of specific classes.

Moreover, teachers also pay attention to students' personal problems to help them to overcome the difficulties and tighten the teacher-student relationship. Maintaining a friendly and mutual-understanding and mutual-respect way of communication with students is always an important criterion to construct a good relationship. In dealing with misbehaviors, teachers need to take students' attitude into consideration before deciding on what treatment should be given. In terms of acquiring knowledge, teachers classify students into groups based on the competence to assign the appropriate tasks. By considering the classroom management style as the initial move, teachers may be able to increase students' motivation in learning, build positive relationships with classmates, and contribute to more effective learning environment.

Results from the present study do not merely inform teachers of their classroom management styles, but it stresses their effect on students' external motivation to learn English as well. Thus, being aware of the strong and weak aspects of one's own classroom management style, teachers can consolidate the characteristics beneficial for students' learning motivation and constrain the detrimental traits also. Although style is determined by many factors including personality, it is still changeable. As the results have shown, Authoritative style is the most fruitful model for encouraging students to learn English. Permissive style is totally harmful to students' learning impulsion. Hence, it is highly recommended that teachers should adopt Authoritative style and eliminate Permissive style when managing their classrooms. Besides, some positive characteristics of Authoritarian and Indulgent styles should also be taken into consideration. To illustrate, teachers should praise their students when they do tasks rightly or spend time to interact with students in/out of classroom. As can be seen, teachers can make full use of the favorable characteristics of each style in order to be the driving force for students' learning. In other words, the flexibility in choosing and combining different styles are necessary.

Another matter arising from the result of this study is that whether teachers should employ and enforce a firm rule and discipline system to control students or not. According to many students, this action can be a stimulus for their learning. In contrast, some other students report that it can demotivate them from learning the subject. Obviously, rules and disciplines are essential to keep the class in order, which enables the teaching and learning to happen. In this case, perhaps the students' individual differences in learning styles are possibly the cause for this phenomenon. Therefore, teachers should study carefully the students' learning styles to decide how rules and disciplines will be formulated. 


\section{Conclusion}

The general conclusion is that different styles affect student's English learning motivation and academic achievement in different levels and dimensions. First, Authoritative teachers appear to be the most positively influential factor to students' learning motivation. This style contributes greatly in driving students to learn the subject, especially when teachers deliver the lessons fluently with modulated voice. However, there is a disagreement between groups of students concerning the impact of rules and disciplines have on students' English learning motivation. Second, Indulgent classroom management style has been reported as creating both positive and negative effect on students' learning interest. In general, the negative effect is of greater part. The most negatively influential characteristic of this style is the little control of teachers over in-class activities. The only trait of this style that has enormously positive impact on students' motivation is teachers' willingness to interact with students in and out of classroom. Third, Authoritarian style mostly has negative to fair influence on students' external motivation except for the common characteristics with Authoritative style. Strikingly, a conflict arises between students as to whether teachers' enforcement of a firm discipline system for misbehaviors could stimulate students to learn English. Lastly, Permissive style is considered to severely affect students' inspiration for achieving English.

\section{References}

Açıkgöz, F. (2005). A study on teacher characteristics and their effects on students' attitudes. The Reading Matrix, 5(2).

Ames, A. C. (1990). Motivation: What teachers need to know. Teacher College Record, 91(3), 409-421.

Anderson, L., Evertson, C., \& Brophy, J.(1979). An experimental study of Effective teaching in first grade reading groups. Elementary School Journal, 79, 193-223. https://doi.org/10.1086/461151

Baumrind, D. (1971). Current Patterns of Parental Authority. Developmental Psychology Monographs, 4(1), 56-67. https://doi.org/10.1037/h0030372

Brophy, J. (1988). Educating teachers about managing classrooms and students. Teaching and Teacher Education, 4(1), 1-18. https:/ / doi.org/10.1016/0742-051x(88)90020-0

Brophy, J., \& Evertson, C. (1976). Learning from teaching: a developmental perspective. Allyn and Bacon.

Brown, H. D. (2007). Principles of Language Learning and Teaching. (5 ${ }^{\text {th }}$ ed.). Pearson Education.

Burden, P. R. (1995). Classroom management and discipline. Longman.

Chamundeswari, S. (2013). Teacher Management Styles and their Influence on Performance and Leadership Development among Students at the Secondary Level. International Journal of Academic Research in Progressive Education and Development, 2(1), 369-381.

Chang, H. L. (2012). Teacher Management Style: Its Impact on Teacher-Student Relationship and Leadership Development. University of Southern California.

Deci, E. (1975). Intrinsic Motivation. Plenum Press.

Deci, L. E., Connell, P. J., \& Ryan, M. R. (1989). Self-determination in a Work Organization. Journal of Applied Psychology, 74(4), 580-590.

Doyle, W. (1986). Classroom organization and management. In M. Wittrock (Ed.), Handbook of Research on Teaching (3rd ed., pp. 392-431). Macmillan. 
Dreikurs, R., Cassel, P., \& Ferguson, E. (2004). Discipline without tears: Plow to reduce conflict and establish cooperation in the classroom. John Wiley \& Sons.

Dunbar, C. (2004). Best practice in classroom management. Michigan State University.

Emmer, T. E., \& Stough, M. L. (2001). Classroom Management: A Critical Part of Educational Psychology, With Implications for Teacher Education. Educational Psychologist, 36(2), 103-112. https://doi.org/10.1207/s15326985ep3602_5

Evertson, M. C., \& Weinstein, S. C. (2006).Handbook of Classroom Management: Research, Practice, and Contemporary Issues. Lawrence Erlbaum Associates.

Gardner, R. C (1985). Social psychology and second language learning: The role of attitudes and motivation. Edward Arnold.

Glasser, W. (1986). Control theory in the classroom. Harper and Row.

Good,T.,\& Grouws, D.(1977). Teaching effects: A process- product study in fourth grade mathematics classrooms. Journal of Teacher Education, 28(3), 49-54.

Hill, J. D. (2003). Crisis and the classroom: A practical guide for teachers. Charles C Thomas Publisher Ltd.

Jones, F. V., \& Jones, S. L. (2007). Comprehensive Classroom Management: Creating Communities of Support and Solving Problems. Pearson Allyn and Bacon.

Keblawi, F. (2009). A Critical Appraisal of Language Learning Motivation Theories. Proceedings of the 5th International Biennial SELF Research Conference, Dubai.

Kounin, J.S. (1970). Discipline and group management in classrooms. Holt, Rinehart \& Winston.

Kratochwill, T. (n.d.). Classroom management: Teachers module. http:/ / www.apa.org/education/k12/classroom-mgmt.aspx

Lyons, J., Ford, M., \& Arthur-Kelly, M. (2011). Classroom management-Creating positive learning environments. Cengage Learning.

Martin, K., Yin, Z., \& Baldwin, B. (1998). Construct validation of the attitudes and beliefs classroom control inventory. Journal of Classroom Interaction, 33(2), 6-15.

Marzano, J. R., \& Marzano, S. J. (2003). The key to classroom management. Building classroom relationships, 61(1), 6-13.

Mitchell, T. (1982). Motivation: New directions for theory research and practice. Academy of Management review, 7(1), 80-88.

Moore, D. K., \& Hansen, J. (2012). Effective Strategies for Teaching in K-8 classrooms. SAGE publications, Inc.

Morehouse, M. M. (2007). An exploration of emotional intelligence across career arenas. Leadership \& Organization Development, 28, 296-307.

Moreno Rubio, C. (2009). Effective teachers -Professional and personal skills. Revista de la Facultad de Educación de Albacete, 24, 35-46.

Tauber, T. R. (1999). Classroom Management: Sound theory and Effective Practice (4th ed.). Bergin \& Garvey.

Ur, P. (1996). A course in Language Teaching. Cambridge University Press.

Waterman, S. (2007). The democratic differentiated classroom. Eye on Education

Weinstein, C. S., \& Mignano, A.J. (1993). Elementary classroom management: Lessons from research and practice. McGraw-Hill.

Wessler, S. L. (2003). Building classroom relationships-It's hard to learn when you're scared. Educational Leadership, 67(1), 40-43.

Wong, H., \& Wong, R. (2005). How to be an effective teacher: The first days of school.

Woolfolk, A. E., \& Hoy, W. K., (1990). Prospective teachers' sense of efficacy and beliefs about control. Journal of Educational Psychology, 82, 81-91. https://doi.org/10.1037/0022-0663.82.1.81 